\title{
Pengaruh Kecerdasan Emosional dan Motivasi Belajar terhadap Prestasi Belajar dengan Tingkat Pemahaman Akuntansi sebagai Variabel Intervening
}

\author{
Tri Indro Afianty Benu ${ }^{1 *}$, Paskah Ika Nugroho ${ }^{2}$ \\ ${ }^{123}$ Fakultas Ekonomika dan Bisnis, Universitas Kristen Satya Wacana \\ *232016189@student.uksw.edu ${ }^{1 *}$
}

\section{Abstrak}

Penelitian ini dilakukan untuk mengetahui bagaimana pengaruh kecerdasan emosional dan motivasi belajar terhadap prestasi belajar dengan tingkat pemahaman akuntansi sebagai variabel intervening. Dalam penelitian ini jenis data yang digunakan merupakan data primer, data diperoleh dengan memakai kuesioner sebagai instrumen penelitian yang kemudian disebarkan kepada 75 responden. Dalam hal ini yang menjadi responden adalah mahasiswa akuntansi angkatan 2017, 2018, dan 2019 Fakultas Ekonomika dan Bisnis Universitas Kristen Satya Wacana. Penelitian ini menggunakan metode kuantitatif berupa survey. Hasil yang diperoleh dari penelitian ini yaitu kecerdasan emosional mempunyai pengaruh yang negatif terhadap prestasi belajar, kecerdasan emosional mempunyai pengaruh yang positif terhadap tingkat pemahaman akuntansi, motivasi belajar mempunyai pengaruh yang positif terhadap prestasi belajar, motivasi belajar mempunyai pengaruh yang positif terhadap tingkat pemahaman akuntansi, tingkat pemahaman akuntansi mempunyai pengaruh yang negatif terhadap prestasi belajar, motivasi belajar mempunyai pengaruh yang negatif terhadap prestasi belajar dengan tingkat pemahaman akuntansi sebagai variabel intervening, kecerdasan emosional mempunyai pengaruh yang negatif terhadap prestasi belajar dengan tingkat pemahaman akuntansi sebagai variabel intervening.

Kata Kunci : Kecerdasan Emosional, Motivasi Belajar, Prestasi Belajar, Tingkat Pemahaman Akuntansi.

\section{Abstract}

This research was conducted to find out how in the influence of emotional intelligence and learning motivation on learning achievement with the level of understanding of accounting as an intervening variable. In this study the type of data used is primary data, data obtained using a questionnaire as a research instrument which is then distributed to 75 respondents. In this case the respondents are accounting student class of 2017, 2018, and 2019, Faculty of Economics and Business, Satya Wacana Christian University. This research uses quantitative methods in the form of survey. The results obtained from this emotional intelligence has a negative effect on learning achievement, emotional intelligence has a positive influence on the level of accounting understanding, learning motivation has a positive influence on learning achievement, learning motivation has a positive influence on the level of accounting understanding, the level of accounting understanding has a negative effect on learning achievement, learning motivation has a negative influence on learning achievement with the level of understanding accounting as an intervening variable, emotional intelligence has a negative effect on learning achievement with the level of understanding accounting as an intervening variable.

Keywords: Emotional Intelligence, Learning Motivation, learning Achievement, Level Understanding of Accounting

\section{Pendahuluan}

Indonesia merupakan negara berkembang, untuk itu Pendidikan menjadi sangat penting agar dapat membantu meningkatkan kemajuan bangsa, salah satunya dalam menghadapi tantangan persaingan global dan kemajuan teknologi dengan menyediakan sumber daya manusia yang professional, karena masa depan bangsa aman ditangan masyarakat yang berpendidikan untuk itu Indonesia perlu meningkatkan mutu generasi muda Bangsa Indonesia, dalam mengatur Negara tersebut. Pendidikan merupakan salah satu sarana untuk
History:
Publisher: Undiksha Press
Received: 03 Maret 2021
Licensed: This work is licensed under
Revised: 26 Juni 2021
a Creative Commons Attribution 3.0 License
Accepted: 28 Juni 2021
Published: 30 Juni 2021 
meningkatkan pengetahuan dan pemahaman, serta dapat dijadikan sebagai bekal untuk masa depan seseorang, dengan melalui suatu proses, yang dapat disebut dengan belajar. UndangUndang Republik Indonesia Nomor 12 Tahun 2012 Tentang Pendidikan Tinggi (2012) sebagai berikut: "Mengembangkan kemampuan dan membentuk watak serta peradaban bangsa yang bermartabat dalam rangka mencerdaskan kehidupan bangsa; mengembangkan Sivitas Akademik yang inovatif, responsif, kreatif, terampil, berdaya saing, dan kooperatif melalui pelaksanaan Tridharma; dan mengembangkan Ilmu Pengetahuan dan Teknologi dengan memperhatikan dan menerapkan nilai Humaniora.

Perguruan tinggi adalah satu Lembaga dari sekian Lembaga lainnya yang melaksanakan proses Pendidikan secara formal. Universitas merupakan salah satu jenjang Pendidikan tinggi yang mempersiapakan mahasiswa yang nantinya dapat terjun ke dunia kerja sesuai dengan keahliannya sesudah mereka lulus, agar bisa bersaing di dalam dunia keja, mahasiswa harus menjadi lulusan yang berprestasi, dengan demikian fungsi dan tujuan dari Pendidikan Tinggi dapat tercapai. Prestasi belajar dapat dijadikan sebagai alat ukur untuk melihat seberapa besar tingkat kemampuan peserta didik dalam bidang tersebut. Belajar merupakan proses pembentukan dari yang tidak tahu menjadi tahu, agar dapat menjadi lebih baik lagi dari yang sebelumnya, baik secara akademik maupun kepribadian. Keberhasilan proses belajar yang diakui dalam Lembaga Pendidikan yaitu melalui prestasi belajar. Akuntansi merupakan salah satu mata kuliah yang mencakup prestasi belajar dari sekian banyak mata kuliah lainnya.

Hasil Pembelajaran biasanya akan dinyatakan dengan nilai atau angka dalam suatu periode tertentu, apabila angka yang didapatkan semakin tinggi maka dapat dinyatakan bahwa semakin baik pemahamannya terhadap pembelajaran. Prestasi belajar adalah nilai tes atau angka nilai yang diberikan guru atas penguasaan pengetahuan atau ketrampilan yang dikembangkan dari mata pelajaran tersebut (Setyorini \& Syahlani 2019). Fitrio et al (2019) menyatakan bahwa prestasi belajar memiliki tiga aspek yaitu; kognitif, afektif dan psikomoter, apabila ketiga aspek tersebut dimiliki maka seseorang dikatakan sempurna dalam berfikir, merasa, dan berbuat. Dalam kenyataanya tidak semua mahasiswa akuntansi memiliki kesempurnaan dari ketiga aspek tersebut, seperti mahasiswa akuntansi di Universitas Kristen Satya Wacana. Masih terdapat beberapa mahasiswa yang memiliki kendala, sehingga ada mahasiswa yang masih kesulitan dalam mencapai nilai yang sesuai dengan batas ketentuan kriteria minimum yang telah ditetapkan oleh dosen.

Prestasi Belajar Akuntansi setiap mahasiswa berbeda, tergantung pada kondisi mereka masing-masing selama berjalannya proses belajar yang diikuti. Setyorini \& Syahlani (2019) menyatakan bahwa terdapat faktor yang mempengaruhi prestasi belajar mahasiswa antara lainnya yaitu, faktor dari dalam diri mahasiswa diantaranya minat, motivasi, tingkat kecerdasar intelektual maupun emosional, adapun faktor dari luar diantaranya kompetensi dosen, kualitas sarana-prasarana dan kondisi sosial ekonomi mahasiswa. Prestasi Belajar Mahasiswa Akuntansi yang masih terbilang rendah dapat disebabkan oleh beberapa faktor diantaranya Tingkat Pemahaman Akuntansi.

Tingkat Pemahaman Akuntansi dinyatakan dengan seberapa megerti seseorang dengan mata kuliah akuntansi yang telah dipelajari (Rimbano \& Putri 2016). Pemahaman yang baik juga merupakan kemampuan seseorang untuk mengerti serta memahami tentang apa yang dipelajari kemudian hal tersebut dapat dijelaskan menggunakan bahasanya sendiri.

Kecerdasan Emosional adalah pengontrolan emosional secara positif yang mana mampu untuk mengenali, mengelola, dan mengontrol emosi. Kecerdasan Emosional merupakan suatu bentuk keseimbangan antara emosi dan pikiran seseorang dalam menerima, menilai dan mengelola suatu hal yang diterimanya. Suprianto \& Harryoga (2016) menyatakan bahwa pencapaian kesuksesan seseorang dalam hidupnya dapat dipengaruhi oleh Kecerdasan Emosional baik kehidupan pribadi ataupun profesional kurang lebih pengaruhnya 
sebesar 80 persen. Penelitian yang dilakukan Nugrahadi \& Rizki (2018) menyatakan bahwa hasil analisis yang diperoleh dari pengolahan data signifikan dan positif dengan demikian dapat disimpulkan bahwa kecerdasan emosional berpengaruh terhadap prestasi belajar siswa.

Motivasi Belajar sangat penting bagi mahasiswa, karena hal tersebut dapat memberikan pengaruh secara tidak langsung kepada prestasi seseorang, yang mana apabila motivasinya tinggi, mahasiswa diharapkan dapat menerima apa yang diajarkan. Motivasi yang tinggi biasanya dilihat dari sifat seseorang yang memiliki perasaan dan keterlibatan dalam belajar serta adanya usaha yang dilakukan agar motivasi tersebut tetap ada. Pada umumunya sebagian orang tidak mempunyai tujuan yang jelas dalam belajar dengan demikian optimalisasi atas motivasi belajar itu sendiri kurang. Motivasi adalah muatan energi dalam diri seseorang yang ditandai oleh gairah afektif dan reaksi tujuan antisipatif (Setyorini \& Syahlani 2019).

Penelitian mengenai prestasi belajar akuntansi sebelumnya sudah pernah dilakukan oleh Chrisna dan Khairani (2019) yang mana meneliti tentang prestasi belajar dengan menggunakan variable independent perilaku belajar, pengendalian diri, motivasi, empati, keterampilan, kepercayaan diri, dan variable dependen nya adalah prestasi akademik mahasiswa Prodi (Program Studi) akuntansi universitas pembangunan panca budi medan, sementara penelitian ini menggunakan variabel dan sampel yang berbeda dari penelitian sebelumnya. Variabel independen dalam penelitian ini adalah kecerdasan emosional, motivasi belajar dan variabel dependen prestasi belajar akuntansi, dalam penelitian ini peneliti menggunakan variabel tambahan yaitu tingkat pemahaman akuntansi sebagai variabel intervening. Penelitian ini juga dilakukan di Fakultas Ekonomika dan Bisnis Universitas Kristen Satya Wacana dengan mengambil sampel dari mahasiswa program studi Akuntansi. Penelitian ini dilakukan agar dapat mengetahui perbedaan penelitian yang pernah dilakukan sebelumnya dengan penelitian yang akan dilakukan ini.

Tujuan penelitian ini adalah (1) mengetahui pengaruh Tingkat Pemahaman Akuntansi terhadap Prestasi Belajar Akuntansi mahasiswa Program Studi Akuntansi Fakultas Ekonomika dan Bisnis Universitas Kristen Satya Wacana; (2) mengetahui pengaruh Kecerdasan Emosional terhadap Prestasi Belajar Akuntansi mahasiswa Program Studi Akuntansi Fakultas Ekonomika dan Bisnis Universitas Kristen Satya Wacana; (3) mengetahui pengaruh Motivasi Belajar terhadap Prestasi Belajar Akuntansi mahasiswa Program Studi Akuntansi Fakultas Ekonomika dan Bisnis Universitas Kristen Satya Wacana; (4) mengetahui pengaruh Tingkat Pemahaman Akuntansi, Kecerdasan Emosional dan Motivasi Belajar terhadap Prestasi Belajar Akuntansi mahasiswa Program Studi Akuntansi Fakultas Ekonomika dan Bisnis Universitas Kristen Satya Wacana.

Manfaat penelitian ini adalah (1) dengan adanya penelitian ini dapat diketahui Pengaruh Tingkat Pemahaman Akuntansi, Kecerdasan Emosional dan Motivasi Belajar terhadap Prestasi Belajar Akuntansi pada mahasiswa program studi Akuntansi Fakultas Ekonomika dan Bisnis Universitas Kristen Satya Wacana; (2) dapat dijadikan sebagai referensi dan informasi untuk penelitian selanjutnya dalam melakukan penelitian di bidang yang sama yaitu Pengaruh Tingkat Pemahaman Akuntansi, Kecerdasan Emosional dan Motivasi Belajar terhadap Prestasi Belajar Akuntansi.

Prestasi adalah hasil usaha yang didapatkan secara individu ataupun kelompok dari suatu kegiatan tertentu yang telah dijalankan dengan baik dan benar (Nugrahadi \& Rizki 2018). Belajar merupakan proses perubahan tingkah laku yang terjadi pada individu dari hasil interaksi nya dengan lingkungan, hal tersebut bisa didapatkan di mana saja, baik di luar maupun di dalam Lembaga Pendidikan. Prestasi belajar merupakan salah satu indikator yang dipakai dalam Lembaga Pendidikan untuk mengukur sejauh manakah proses pembelajaran seseorang. Fitrio et al. (2019) menyatakan bahwa prestasi belajar merupakan berbagai 
kemampuan dari siswa, yang mana hal tersebut didapatkan sesudah menjalankan proses belajar. Prestasi belajar adalah pengaruh permanen pada perilaku, pengetahuan, dan pola berpikir, yang didapatkan dari pengalaman (Setyorini \& Syahlani, 2019). Prestasi belajar merupakan hasil berupa nilai yang didapatkan seseorang dalam sebuah kegiatan ataupun tugas tertentu (Novianto \& Subkhan 2015).

Suprianto \& Harryoga (2016) menyatakan bahwa akuntansi merupakan suatu proses dalam melakukan identifikasi, pengukuran, dan memberikan laporan mengenai informasi ekonomi untuk memungkinkan adanya penilaian dan pengambilan keputusan bagi pihak pengguna informasi tersebut. Pihak yang memakai informasi akuntansi menyadari bahwa akuntansi merupakan suatu aktivitas jasa yang menyediakan informasi yang dibutuhkan dalam sebuah perencanaan, pengawasan, serta pengambilan keputusan. Akuntansi adalah suatu aktivitas penyediaan jasa informasi tertentu dalam pembuatan perencanaan, pengawasan, serta pengambilan keputusan, hal ini merupakan pandangan yang dilihat dari pihak pengguna informasi akuntansi.

Prestasi belajar merupakan hasil belajar yang dicapai seorang mahasiswa dalam aspek pengetahuan khususnya dalam kegiatan yang berkaitan dengan identifikasi dan pengukuran transaksi laporan keuangan, hal tersebut dapat diukur melalui tes dan kemudian hasil tersebut dapat dinyatakan berupa angka. Prestasi belajar bisa digunakan sebagai pendorong dalam meningkatkan ilmu pengetahuan seseorang.

Kecerdasan Emosional adalah pengontrolan emosional secara positif yang mana mampu untuk mengenali, mengelola, dan mengontrol emosi. Kecerdasan Emosional merupakan suatu bentuk keseimbangan antara emosi dan pikiran seseorang dalam menerima, menilai dan mengelola suatu hal yang diterimanya. Nugrahadi \& Rizki (2018) menyatakan bahwa kecerdasan emosional merupakan adanya respons seseorang akan hal-hal atau masalah yang berada di lingkungan sekitarnya. Kecerdasan Emosional memiliki peran yang penting dalam pencapaian kesuksesan hidup seseorang, baik kehidupan pribadi ataupun profesional kurang lebih pengaruhnya sebesar 80 persen (Suprianto \& Harryoga 2016). Nugrahadi \& Rizki (2018) menyatakan bahwa hasil analisis yang diperoleh dari pengolahan data signifikan dan positif dengan demikian dapat disimpulkan bahwa kecerdasan emosional berpengaruh terhadap prestasi belajar siswa.

Pengertian di atas dapat disimpulkan bahwa kecerdasan emosional ialah kemampuan seseorang dalam mengenali emosi yang ada pada diri sendiri dan orang lain, dengan demikian kemampuan tersebut dapat digunakan untuk memandu pikiran dan tindakan seseorang dengan tepat dalam menghadapi suatu masalah yang terjadi di lingkungan sekitarnya, karena adanya pengontrolan emosional secara positif yaitu kemampuan mengenal, menilai dan mengelola emosi pada diri.

Motivasi belajar muncul karena adanya factor intrinsik, berupa kemauan dan keinginan untuk berhasil dan dorongan kebutuhan belajar, juga adanya harapan dan cita-cita. Factor ekstrinsik nya adalah penghargaan, lingkungan belajar yang mendukung, dan kegiatan belajar yang menarik. Namun, kedua faktor dapat berjalan apabila adanya rangsangan tertentu, sehingga adanya keinginan untuk belajar dan semangat lebih tinggi.

Seseorang melakukan sesuatu karena adanya segala daya yang mendorong, hal tersebut disebut dengan motivasi (Setyorini \& Syahlani 2019). Nugrahadi \& Rizki (2018) menyatakan bahwa Motivasi memiliki peran penting dalam mendorong seseorang untuk aktif melakukan sesuatu. Motivasi juga berfungsi sebagai dasar bagi seseorang untuk terlibat dan ikut serta dalam sebuah aktivitas. Guru dapat mengatur aktivitas pembelajaran itu agar kreatif sehingga siswa terus termotivasi mengikuti pembelajaran di dalam kelas. Fitrio et al. (2019) Menyatakan bahwa motivasi merupakan daya penggerak yang sudah menjadi aktif, arti ini berasal dari kata motif. Secara garis besar dapat dikatakan bahwa motivasi belajar merupakan 
suatu dorongan yang ditandai dengan adanya reaksi dalam melakukan kegiatan pembelajaran agar dapat mencapai tujuan yang ingin dicapai.

Akuntansi merupakan ilmu yang konsentrasinya berbicara tentang permasalahan keuangan. Perkembangan teknologi sangat penting di dalam akuntansi, karena dengan adanya perkembangan teknologi maka akan lebih mudah dan praktis dalam dunia bisnis. Mahasiswa dapat dikatakan memahami atau menguasai akuntansi apabila ilmu akuntansi yang telah diperoleh dari pembelajaran dapat digunakan dalam praktik di dunia kerja. Pemahaman merupakan kemampuan berpikir yang lebih tinggi dari pada sekadar ingatan atau hafalan dan juga hasil atau nilai tes. Apabila pembelajaran dapat dipahami dengan baik oleh mahasiswa maka konsekuensi logis dari pembelajaran tersebut adalah nilai.

Pemahaman akuntansi adalah orang yang pandai dan benar-benar mengerti tentang akuntansi, hal tersebut dapat diukur dengan melihat nilai matakuliah yang di dalamnya terdapat unsur-unsur yang menggambarkan akuntansi secara umum (Parauba 2014). Rokhana \& Sutrisno (2016) menyatakan bahwa seberapa mengerti seorang mahasiswa dapat dilihat dari tingkat pengertian dan penguasaan konsep-konsep terkait dengan akuntansi, bukan dari nilai yang didapatkan dalam mata kuliah saja. Dengan begitu dapat diketahui seberapa cukupkah ilmu akuntansi yang sudah dimiliki seorang akuntan agar dapat melaksanakan peran profesi akuntan di dunia bisnis. Pemahaman akuntansi merupakan sejauh mana kemampuan untuk memahami akuntansi sebagai kesatuan pengetahuan ataupun sebagai praktik maupun proses (Mutia 2015).

Model dalam penelitian yang akan dilakukan ini adalah tentang pengaruh kecerdasan emosional, motivasi belajar dan tingkat pemahaman akuntansi terhadap prestasi belajar. Untuk mengembangkan hipotesis dapat dilihat pada gambar di bawah. Variabel yang digunakan dalam penelitian ini adalah variabel independent, yaitu pengaruh kecerdasan emosional dan motivasi belajar, variabel dependen dalam penelitian ini adalah prestasi belajar, dan tingkat pemahaman akuntansi sebagai variabel intervening.

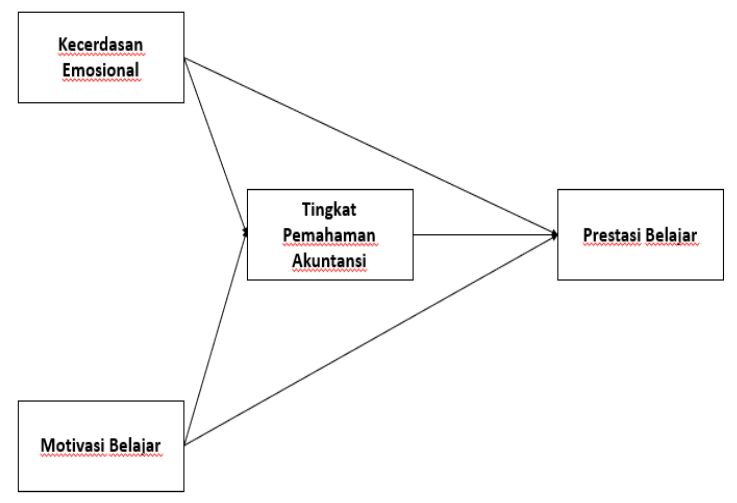

Gambar 1. Model Penelitian

Kecerdasan manusia dapat dilihat dari ukuran kecerdasan intelektual, kecerdasan spiritual, kecerdasan transendental, maupun kecerdasan emosional. Kecerdasan emosional adalah pengontrolan emosional secara positif dimana hal tersebut mampu untuk mengenali, mengelola, dan mengontrol emosi. Baik atau buruknya kecerdasan emosional yang dimiliki mahasiswa dapat mempengaruhi proses belajarnya. Apabila mahasiswa memiliki kecerdasan emosional yang baik maka pada proses belajarnya akan ikut baik, karena mahasiswa dapat mengarahkan perasaannya secara tepat sehingga tidak terpengaruh dengan perasaan senang 
dan sedihnya yang akan membuat mereka berlarut dalam kondisi tersebut. Dengan demikian, jika proses belajarnya baik, maka akan memberikan nilai akhir yang baik pula.

Nugrahadi \& Rizki (2018) menyatakan bahwa adanya pengaruh yang positif dan signifikan yang terjadi antara variabel kecerdasan emosional terhadap prestasi belajar. Sari et al (2015) menjelaskan bahwa kecerdasan emosional berpengaruh positif dan signifikan terhadap hasil belajar akuntansi. Hal tersebut ditandai dengan adanya kenyamanan pada siswa ketika melakukan proses belajar, sehingga siswa dapat menjadi tekun dan bersungguhsungguh dalam belajar dengan demikian hasil belajar yang diperoleh siswa baik/tinggi.

\section{$H_{1}$ : Kecerdasan emosional berpengaruh positif terhadap prestasi belajar}

Motivasi merupakan daya pendorong bagi mahasiswa agar dapat melakukan suatu pekerjaan. Motivasi belajar itu sendiri bisa datang dari dalam diri atau dari luar, seperti lingkungan. Motivasi mahasiswa yang tinggi, ditandai dengan rasa ingin tahu, sehingga mahasiswa menjadi aktif dalam kegiatan belajar. hal ini membuat prestasi belajar siswa menjadi meningkat. Motivasi belajar dapat memberikan pengaruh terhadap perilaku belajar siswa, motivasi mendorong meningkatkan semangat dan ketekunan dalam belajar.

Motivasi belajar mempunyai peran yang penting dalam meningkatkan semangat dan rasa senang dalam belajar, dengan begitu siswa yang mempunyai motivasi yang tinggi, memiliki banyak kekuatan untuk melakukan kegiatan belajar yang pada akhirnya membuat siswa mampu mendapatkan perolehan prestasi yang lebih baik. Terdapat pengaruh motivasi belajar yang positif dan signifikan terhadap prestasi belajar siswa (Nugrahadi \& Rizki 2018). Hal ini serupa dengan Fitrio et al. (2019) yang menyatakan bahwa secara parsial motivasi berpengaruh positif dan signifikan terhadap prestasi belajar.

$\mathrm{H}_{2}$ : Motivasi Belajar berpengaruh positif terhadap prestasi belajar.

Kecerdasan emosional seseorang dapat dikatakan baik apabila memiliki kemampuan untuk mengenal diri sendiri, mengendalikan diri, memotivasi diri, berempati dan kemampuan social. Dengan demikian mahasiswa yang memiliki keterampilan emosi yang baik akan berhasil di dalam kehidupan dan memiliki motivasi belajar terus-menerus. Sedangkan, mahasiswa yang sebaliknya memiliki keterampilan emosi yang kurang baik, akan kurang dalam memiliki motivasi untuk belajar, hal tersebut dapat mengurangi kemampuan untuk berfokus pada tugasnya sebagai mahasiswa.

Suprianto \& Harryoga (2016) telah melakukan penelitian mengenai faktor-faktor penentu tingkat pemahaman akuntansi, dalam penelitian tersebut dinyatakan bahwa terdapat pengaruh positif secara signifikan antara kecerdasan emosional terhadap tingkat pemahaman akuntansi. Rokhana \& Sutrisno (2016) menyatakan bahwa kecerdasan emosional berpengaruh signifikan terhadap tingkat pemahaman akuntansi, hal tersebut menyatakan bahwa dalam proses belajar diperlukan pembelajaran yang sesuai dengan tujuan Pendidikan, sehingga dengan perilaku belajar yang benar tujuan Pendidikan dapat dicapai secara efektif dan efisien serta prestasi akademik semakin meningkat. Kecerdasan emosional berpengaruh signifikan positif terhadap tingkat pemahaman mahasiswa akuntansi. Dimana semakin tinggi kecerdasan emosional maka semakin baik tingkat pemahaman akuntansi pada mahasiswa. $H_{3}$ : Kecerdasan emosional berpengaruh positif terhadap tingkat pemahaman akuntansi

Motivasi belajar mempunyai peran yang penting dalam meningkatkan semangat dan rasa senang dalam belajar, dengan begitu siswa yang mempunyai motivasi yang tinggi, memiliki banyak kekuatan untuk melakukan kegiatan belajar karena adanya rasa ingin tahu yang tinggi dan pada akhirnya membuat siswa memiliki tingkat pemahaman yang tinggi. 
Aulia \& Subowo (2016) melakukan penelitian tentang Pengaruh Pengendalian Diri, Motivasi, Dan Perilaku Belajar Terhadap Tingkat Pemahaman Akuntansi Mahasiswa. Hasil penelitian menunjukkan bahwa secara parsial motivasi berpengaruh secara signifikan terhadap pemahaman akuntansi mahasiswa. Hasil dari tingkat pemahaman akuntansi yang dipengaruhi oleh variabel motivasi yaitu positif. Hal ini dapat diartikan bahwa semakin besar tingkat motivasi mahasiswa, seperti dorongan, prestasi, komitmen, inisiatif, dan optimism maka akan semakin tinggi pula tingkat pemahaman akuntansi mahasiswa.

$\mathrm{H}_{4}$ : Motivasi belajar berpengaruh positif terhadap tingkat pemahaman akuntansi

Tinggi atau rendahnya tingkat pemahaman akuntansi pada seorang mahasiswa dapat berpengaruh prestasi belajar yang diperoleh. Apabila tingkat pemahaman akuntansi yang dimiliki oleh mahasiswa tinggi maka dapat meningkatkan nilai tes mata kuliah dan juga IPK (Indeks Prestasi Kumulatif) yang diperoleh. Begitupun sebaliknya, ketika mahasiswa memiliki tingkat pemahaman akuntansi yang rendah maka nilai tes pada mata kuliah dan juga IPK (Indeks Prestasi Kumulatif) yang diperoleh menurun.

Palgunadi \& Rohayati (2014) melakukan penelitian tentang Pengaruh Hasil Belajar Matematika, Ekonomi dan Minat Belajar Terhadap Tingkat Pemahaman Akuntansi. Berdasarkan hasil penelitian menunjukkan bahwa pengaruh variabel hasil belajar matematika $\left(\mathrm{X}_{1}\right)$, hasil belajar ekonomi $\left(\mathrm{X}_{2}\right)$ dan minat belajar $\left(\mathrm{X}_{3}\right)$, secara bersama-sama terhadap tingkat pemahaman akuntansi adalah sebesar 0,337 atau 33,7\% dipengaruhi. Secara bersamasama (simultan) berpengaruh positif.

$H_{5}$ : Tingkat pemahaman akuntansi berpengaruh positif terhadap prestasi belajar

\section{Metode}

Populasi dalam penelitian ini adalah mahasiswa Program Studi Akuntansi Fakultas Ekonomi dan Bisnis Universitas Kristen Satya Wacana yang masih aktif dalam perkuliahan. Sampel dalam penelitian ini adalah mahasiswa jurusan akuntansi angkatan 2017, 2018, dan 2019 karena angkatan pada ketiga tahun tersebut merupakan angkatan yang masih aktif dalam menjalankan perkuliahan.

Jenis data yang akan dipakai dalam melakukan penelitian ini adalah data kuantitatif, yang mana data tersebut merupakan data yang berisi tentang informasi jumlah suatu sampel yang akan digunakan. Data dan informasi yang diperlukan dalam penelitian ini bersumber dari data primer. Data primer adalah pengambilan data secara langsung oleh peneliti dari responden melalui angket penelitian yang diberikan. Dalam hal ini data primer yaitu data yang diperoleh dari hasil penyebaran kuesioner yang diedarkan kepada Mahasiswa Jurusan Akuntansi Fakultas Ekonomi dan Bisnis Universitas Kristen Satya Wacana.

Data dikumpulkan melalui survey dengan melakukan penyebaran kuesioner kepada responden yang akan dilakukan secara langsung kepada yang bersangkutan. Penyebaran kuesioner akan dilakukan dengan cara mengirimkan email kepada calon responden dan menanyakan kesediaannya untuk melakukan pengisian kuesioner. Metode ini dilakukan untuk mendapatkan data yang berhubungan langsung dengan tujuan dari penelitian yaitu tentang pengaruh dari kecerdasan emosional dan motivasi belajar terhadap prestasi belajar dengan tingkat pemahaman akuntansi sebagai variabel intervening.

Metode yang digunakan dalam mengumpulkan sampel adalah probability sampling yang merupakan cara pengumpulan sampel dengan memberikan kesempatan yang sama untuk diambil kepada setiap elemen populasi. Pengambilan sampel pada metode ini menggunakan simple random sampling yang merupakan pengambilan sampel dari anggota populasi dengan menggunakan acak tanpa memperhatikan tingkatan dalam anggota populasi tersebut. 
Penelitian ini menggunakan tiga jenis variabel, yang mana kecerdasan emosional dan motivasi belajar sebagai variabel independen, kemudian variabel dependen nya yaitu prestasi belajar, dan tingkat pemahaman akuntansi sebagai variabel intervening. Dalam menguji suatu variabel, maka perlu diketahui tentang definisi dari masing-masing variabel, kemudian melihat indikator yang terdapat pada setiap variabel yang akan diuji dan masuk dalam kategori pada skala jenis apa. Dalam penelitian ini variabel independen yang digunakan ada dua yaitu kecerdasan emosional $\left(\mathrm{X}_{1}\right)$ dan motivasi belajar $\left(\mathrm{X}_{2}\right)$, sedangkan variabel dependen nya adalah prestasi belajar $(\mathrm{Y})$, dalam penelitian ini terdapat variabel intervening yaitu tingkat pemahaman akuntansi (XY).

Tabel 1. Definisi Operasional Penelitian

\begin{tabular}{|c|c|c|c|}
\hline $\begin{array}{c}\text { Jenis } \\
\text { Variabel }\end{array}$ & Definisi & Indikator & Skala \\
\hline $\begin{array}{l}\text { Kecerdasan } \\
\text { Emosional } \\
(\mathrm{X} 1)\end{array}$ & 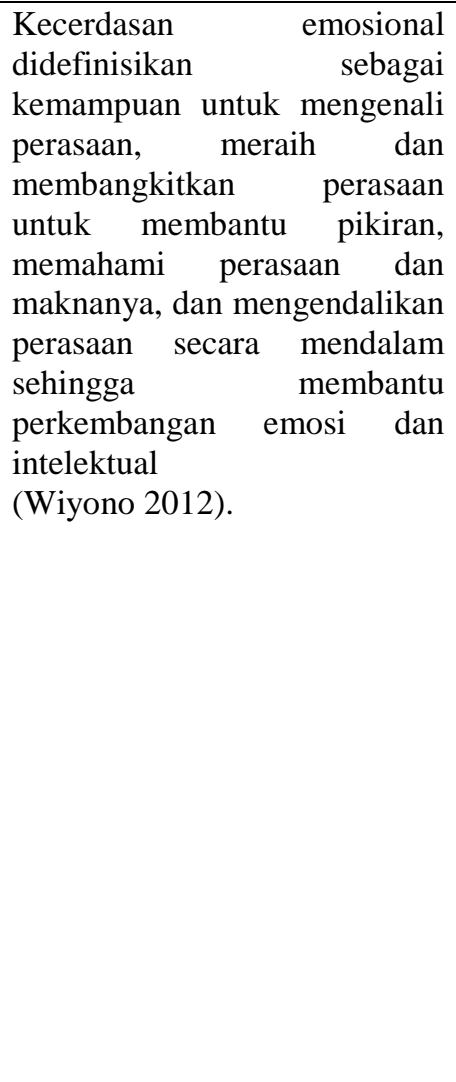 & 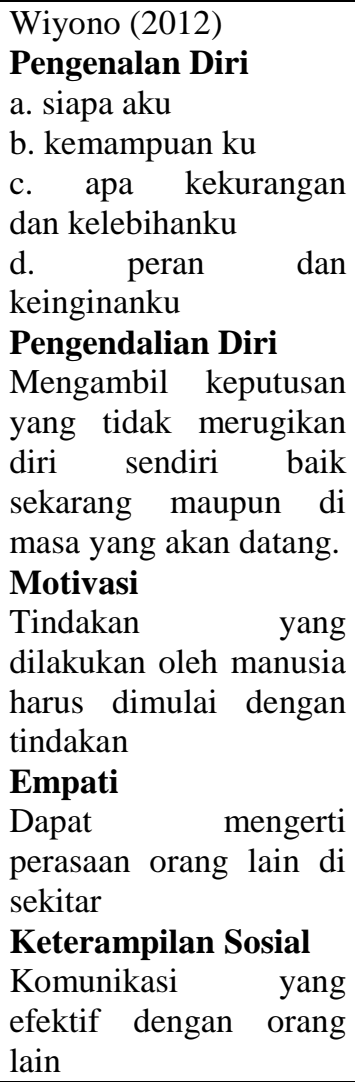 & Skala Likert \\
\hline $\begin{array}{l}\text { Motivasi } \\
\text { Belajar (X2) }\end{array}$ & $\begin{array}{l}\text { Motivasi belajar merupakan } \\
\text { faktor psikis yang sifatnya } \\
\text { non-intelektual (Novita 2017). }\end{array}$ & $\begin{array}{l}\text { Lestari (2013) } \\
\text { a. adanya hasrat dan } \\
\text { keinginan berhasil } \\
\text { b. adanya dorongan dan } \\
\text { kebutuhan dalam } \\
\text { belajar } \\
\text { c. adanya cita-cita dan } \\
\text { harapan di masa depan } \\
\text { d. adanya penghargaan } \\
\text { dalam belajar } \\
\text { e. adanya kegiatan yang } \\
\text { menarik dalam belajar } \\
\text { f. adanya lingkungan } \\
\text { belajar yang kondusif }\end{array}$ & Skala Likert \\
\hline $\begin{array}{l}\text { Prestasi } \\
\text { Belajar (Y) }\end{array}$ & $\begin{array}{l}\text { Prestasi belajar adalah hasil } \\
\text { usaha yang merupakan bukti } \\
\text { dari aktivitas pembelajaran }\end{array}$ & $\begin{array}{l}\text { Hutahahean (2015) } \\
\text { a. bertanggung jawab } \\
\text { atas keberhasilan dalam }\end{array}$ & Skala Likert \\
\hline
\end{tabular}




\begin{tabular}{|c|c|c|}
\hline & $\begin{array}{l}\text { yang telah } \\
\text { (Hutahahean 2015). }\end{array}$ & $\begin{array}{l}\text { menyelesaikan tugas. } \\
\text { b. dapat menghadapi } \\
\text { tingkatan risiko belajar } \\
\text { yang moderat. } \\
\text { c. adanya umpan balik } \\
\text { atas prestasi. }\end{array}$ \\
\hline $\begin{array}{l}\text { Tingkat } \\
\text { Pemahaman } \\
\text { Akuntansi } \\
\text { (XY) }\end{array}$ & $\begin{array}{l}\text { Tingkat } \\
\text { akuntansi dapat diukur dari } \\
\text { seberapa besar pemahaman } \\
\text { seseorang tentang akuntansi } \\
\text { setelah mempelajarinya } \\
\text { ( Rimbano \& Putri 2016). }\end{array}$ & $\begin{array}{l}\text { Rimbano \& Putri } \\
\text { (2016) } \\
\text { a. dapat dilihat dari nila } \\
\text { yang didapatkan dalam } \\
\text { mata kuliah } \\
\text { b. dapat menguasai } \\
\text { konsep-konsep } \\
\text { akuntansi } \\
\text { c. dapat } \\
\text { mengaplikasikan dalam } \\
\text { dunia kerja. }\end{array}$ \\
\hline
\end{tabular}

Penelitian ini dilakukan dengan menggunakan metode yang berbasis variant atau biasa disebut dengan Partial Least Square (PLS). Pengujian validasi dalam penelitian ini dilakukan dengan menggunakan Partial Least Square (PLS) yang mana dilakukan pengujian dengan convergent validity dan discriminantvalidity. convergent validity bertujuan untuk mengetahui validitas setiap hubungan antara indikator dengan variabel latennya. Penilaian validitas dilakukan berdasarkan korelasi antara skor item atau component score dengan skor variable laten atau loading score yang dihitung dengan PLS. Kelayakan model dapat dilihat dari nilai t-statistiknya, dengan syarat t-statistik harus lebih besar dari t-hitung. Discriminant validity digunakan untuk membuktikan bahwa konstruk laten memprediksi ukuran pada blok.

Uji reliabilitas dilakukan dengan melihat nilai composite reliability yang dihasilkan dengan perhitungan PLS untuk masing-masing konstruksi. Apabila nilai composite reliability yang dihasilkan >0,7 maka nilai konstruksi nya dapat dikatakan reliabel (Janti 2014). Penilaian model struktural dengan PLS dimulai dengan melihat $R$-square untuk setiap variabel dependen yang tersembunyi tetapi mempunyai kemungkinan untuk muncul. Fitriani \& Otok (2013) Menyatakan bahwa jika dalam model struktural memberi hasil hasil $\mathrm{R}^{2}>0,5$ maka hal tersebut mengindikasikan bahwa model yang didapat "baik". Uji hipotesis dalam penelitian ini menggunakan model persamaan struktural (inner model), yang mana model struktural diukur dengan memakai nilai T-Statistic konstruksi dependen, nilai beta koefisien untuk hipotesis two tailed (Wibowo \& Sutanto 2013).

\section{Hasil dan Pembahasan}

Hasil penyebaran kuesioner yang dilakukan kepada 75 mahasiswa S1 Program Studi Akuntansi Fakultas Ekonomika dan Bisnis Universitas Kristen Satya Wacana yang mana terdiri dari angkatan 2017, 2018, dan 2019. Kuesioner yang kembali yaitu berjumlah 68 kuesioner dan kemudian dapat diolah untuk di analisis dan uji. Tingkat pengembalian kuesioner dapat dilihat pada tabel 2.

Tabel 2. Tingkat Pengembalian Kuesioner

\begin{tabular}{lcc}
\hline \multicolumn{1}{c}{ Kriteria } & Jumlah & Persentase \\
\hline Kuesioner yang disebar & 75 & $100 \%$ \\
\hline Jumlah Kuesioner yang tidak kembali & 7 & $9,3 \%$ \\
\hline Jumlah Kuesioner yang tidak lengkap & 0 & $0 \%$ \\
\hline Jumlah Kuesioner yang kembali & 68 & $90,7 \%$ \\
\hline
\end{tabular}


Data deskriptif akan menjelaskan tentang gambaran kondisi responden yang dapat diperhatikan sebagai informasi tambahan untuk memahami hasil dari penelitian. Kuesioner yang disebarkan sebanyak 23 orang merupakan mahasiswa angkatan 2017, 22 orang angkatan 2018 dan 23 orang lainnya merupakan angkatan 2019 dari S1 Program Studi Akuntansi Fakultas Ekonomika dan Bisnis Universitas Kristen Satya Wacana.

Tabel 3. Karakteristik responden berdasarkan angkatan

\begin{tabular}{|c|c|c|}
\hline Angkatan & Frekuensi & Persentase \\
\hline 2017 & 23 & $33,8 \%$ \\
\hline 2018 & 22 & $32,4 \%$ \\
\hline 2019 & 23 & $33,8 \%$ \\
\hline
\end{tabular}

menyajikan sebuah data. Dalam hal ini rata-rata skor jawaban dari setiap variabel yang dipakai dalam penelitian ini merupakan data yang dimaksudkan. Variabel tersebut adalah kecerdasan emosional, motivasi belajar, prestasi belajar dan tingkat pemahaman akuntansi. Pengukuran skor jawaban pada setiap variabel menggunakan skor terendah yaitu 1(sangat setuju) dan skor tertinggi yaitu 5 (sangat tidak setuju), karena penelitian yang dilakukan ini berpedoman pada skor terendah dan tertinggi, maka interval yang dapat diperoleh sebagai berikut:

Interval $=($ nilai maksimal - nilai minimal $) /($ jumlah kelas $)=(5-1) / 5=0.8$

Berdasarkan pada perhitungan diatas, maka skala distribusi kriteria pendapat adalah sebagai berikut:

Tabel 4. Skala distribusi kriteria pendapat

\begin{tabular}{ccccc}
$\begin{array}{c}\text { Sangat } \\
\text { Rendah }\end{array}$ & Rendah & Cukup & Tinggi & Sangat Tinggi \\
\hline $1.00-1.79$ & $1.80-2.59$ & $2.60-3,39$ & $3.40-4.19$ & $4.20-5.00$
\end{tabular}

Berdasarkan hasil analisis yang terdapat pada tabel lampiran 7, diketahui rata-rata penilaian responden terhadap kecerdasan emosional masuk dalam kategori tinggi dengan nilai rata-ratanya sebesar 3.773 , penilaian tertinggi terdapat pada kode pertanyaan X1.6 sebesar 4.721 dan penilaian terendah terdapat pada kode pertanyaan X1.7 sebesar 2.824 dengan demikian dapat dinyatakan bahwa kecerdasan emosional dapat memberikan pengaruh yang tinggi kepada mahasiswa.

Berdasarkan hasil analisis yang terdapat pada tabel lampiran 8, diketahui rata-rata penilaian responden terhadap motivasi belajar masuk dalam kategori sangat tinggi dengan nilai rata-ratanya sebesar 4.203 , penilaian tertinggi terdapat pada kode pertanyaan X2.5 sebesar 4.574 dan penilaian terendah terdapat pada kode pertanyaan X2.2 sebesar 3.691 dengan demikian dapat dinyatakan bahwa motivasi belajar dapat memberikan pengaruh yang tinggi kepada mahasiswa, sehingga mahasiswa sangat giat dalam belajar untuk mendapatkan nilai yang baik.

Berdasarkan hasil analisis yang terdapat pada tabel lampiran 9, diketahui rata-rata penilaian responden terhadap prestasi belajar masuk dalam kategori tinggi dengan nilai rataratanya sebesar 3.990, penilaian tertinggi terdapat pada kode pertanyaan Y.3 sebesar 4.397 dan penilaian terendah terdapat pada kode pertanyaan Y.4 sebesar 3.368 dengan demikian dapat dinyatakan bahwa prestasi belajar memiliki kriteria dengan rata-rata total tinggi sebesar 3.990 .

Berdasarkan hasil analisis yang terdapat pada tabel lampiran 10, diketahui rata-rata penilaian responden terhadap tingkat pemahaman akuntansi masuk dalam kategori tinggi 
dengan nilai rata-ratanya sebesar 3.722, penilaian tertinggi terdapat pada kode pertanyaan XY.2 sebesar 4.029 dan penilaian terendah terdapat pada kode pertanyaan XY.4 sebesar 3.221 dengan demikian dapat dinyatakan bahwa tingkat pemahaman akuntansi dapat memberikan pengaruh yang tinggi kepada mahasiswa dengan rata-rata total tinggi sebesar 3.722 .

Berdasarkan tabel convergent validity semua variabel pada tabel kecerdasan emosional memiliki nilai $<0.70$ hal ini dapat dibuktikan dengan melihat tabel pada lampiran 11 , sedangkan pada motivasi belajar X2.2, X2.4, X2.5, X2.6, X2.7, dilihat pada tabel lampiran 12. prestasi belajar Y1, Y2, Y3, Y4, Y5, Y8 dapat dilihat pada tabel lampiran 13, dan pada tingkat pemahaman akuntansi yaitu XY1, XY3, XY5, XY7, dapat dilihat pada tabel lampiran 14, untuk itu akan dibuat ulang model pengukuran dengan mengeluarkan variabel-variabel tersebut agar tidak mempengaruhi hasil bootstrapping.

Berdasarkan pernyataan di atas kita harus mengeluarkan variabel yang nilai Outer Loading $<0,70$ satu per satu dalam setiap variabel agar pada tahap selanjutnya tidak mempengaruhi hasil bootstrapping. Berdasarkan Model baru yang terdapat pada lampiran 15 dapat dilihat bahwa semua nilainya $>0,70$, yang mana terdiri dari $\mathrm{X} 1.11, \mathrm{X} 1.12, \mathrm{X} 1.13$, X1.20, X2.1, X2.2, X2.3, XY.2, XY.4, XY.5, XY.6, Y.4, Y.6, Y.7. sehingga semua variabel sudah memenuhi kaidah dalam model pengukuran dan dapat dilanjutkan untuk pengujian selanjutnya.

Berdasarkan pada tabel 16, nilai cross loading pada masing-masing item memiliki nilai yang lebih besar dari nilai square root average variance extracted (AVE), dan nilainya paling besar saat dihubungkan dengan variabel laten nya dibandingkan dengan pada saat dihubungkan dengan variabel laten yang lain. Hal tersebut menunjukkan bahwa setiap variabel yang ada dalam penelitian ini sudah mampu untuk menjelaskan variabel laten nya dan sudah membuktikan bahwa discriminant Validity pada setiap item sudah valid.

Tabel 5. Composite Reliability

\begin{tabular}{cccc}
\hline Variabel & $\begin{array}{c}\text { Cronbach's } \\
\text { Alpha }\end{array}$ & $\begin{array}{c}\text { Composite } \\
\text { Reliability }\end{array}$ & $\begin{array}{c}\text { Average Variance } \\
\text { Extracted (AVE) }\end{array}$ \\
\hline Kecerdasan Emosional & 0,756 & 0,844 & 0,576 \\
\hline Motivasi Belajar & 0,801 & 0,884 & 0,717 \\
\hline Prestasi Belajar & 0,705 & 0,835 & 0,628 \\
\hline $\begin{array}{c}\text { Tingkat Pemahaman } \\
\text { Akuntansi }\end{array}$ & 0,769 & 0,851 & 0,588 \\
\hline
\end{tabular}

Pengujian reliabilitas baik yang menggunakan Cronbach's Alpha ataupun Composite Reliability semua nilainya $>0,70$ dan pada pengujian validitas dengan menggunakan AVE (Average Variance Extracted) nilainya 0.50, dapat dilihat pada tabel 2 di atas. Oleh karena itu, dapat disimpulkan bahwa variabel-variabel yang diuji ini valid dan reliable, sehingga hal tersebut dapat dilanjutkan untuk melakukan penguji model struktural.

Kriteria penerimaan atau penolakan hipotesis yaitu jika nilai signifikansi t-value $>1,96$ dan atau nilai p-value $<0,05$ pada tarif signifikansi 5\% ( $\alpha 5 \%)$ maka Ha diterima dan Ho ditolak, sebaliknya jika nilai signifikansi t-value $<1,96$ dan atau nilai p-value $>0,05$ pada tarif signifikansi 5\% ( $\alpha$ 5\%) maka Ha ditolak dan Ho diterima.

Berdasarkan pada tabel yang terdapat di lampiran 17, dapat diketahui bahwa konstruksi kecerdasan emosional mempunyai pengaruh positif yang signifikan $(\mathrm{O}=0,183)$ dengan konstruksi prestasi belajar. Nilai t - statistic pada hubungan konstruksi ini adalah 1,785 < 1.96 dan nilai $\mathrm{p}$ - value $0.075>0,05$. Oleh karena itu, hipotesis pertama menyatakan bahwa kecerdasan emosional mempunyai pengaruh yang positif terhadap prestasi belajar tidak terbukti. 
Diketahui bahwa konstruksi kecerdasan emosional mempunyai pengaruh positif yang signifikan $(\mathrm{O}=0.413)$ dengan konstruksi tingkat pemahaman akuntansi. Nilai t - statistic pada hubungan konstruksi ini adalah 4,630 > 1.96 dan nilai $\mathrm{p}-$ value $0.000<0,05$. Oleh karena itu, hipotesis kedua menyatakan bahwa kecerdasan emosional mempunyai pengaruh yang positif terhadap tingkat pemahaman akuntansi terbukti.

Diketahui bahwa konstruksi motivasi belajar mempunyai pengaruh positif yang signifikan $(\mathrm{O}=0.587)$ dengan konstruksi prestasi belajar. Nilai $\mathrm{t}$ - statistic pada hubungan konstruksi ini adalah 7,480 > 1.96 dan nilai $\mathrm{p}$ - value $0.000<0,05$. Oleh karena itu, hipotesis ketiga menyatakan bahwa motivasi belajar mempunyai pengaruh yang positif terhadap prestasi belajar terbukti.

Diketahui bahwa konstruksi motivasi belajar mempunyai pengaruh positif yang signifikan $(\mathrm{O}=0.267)$ dengan konstruksi tingkat pemahaman akuntansi. Nilai t - statistic pada hubungan konstruksi ini adalah $2.192>1.96$ dan nilai $\mathrm{p}-$ value $0.029<0,05$. Oleh karena itu, hipotesis keempat menyatakan bahwa motivasi belajar mempunyai pengaruh yang positif terhadap tingkat pemahaman akuntansi terbukti.

Diketahui bahwa konstruksi tingkat pemahaman akuntansi mempunyai pengaruh positif yang signifikan $(\mathrm{O}=0,166)$ dengan konstruksi prestasi belajar. Nilai t - statistic pada hubungan konstruksi ini adalah $1.634<1.96$ dan nilai $\mathrm{p}-$ value $0.103>0,05$. Oleh karena itu, hipotesis kelima menyatakan bahwa tingkat pemahaman akuntansi mempunyai pengaruh yang positif terhadap prestasi belajar tidak terbukti.

Untuk mengetahui seberapa jauh variabel tingkat pemahaman akuntansi bisa mediasi hubungan antara motivasi belajar dan prestasi belajar dapat dilihat pada tabel lampiran 18, dari tabel tersebut bisa dilihat bahwa hubungan motivasi belajar terhadap prestasi belajar yang di mediasi oleh tingkat pemahaman akuntansi mempunyai pengaruh positif yang signifikan $(\mathrm{O}=0,044)$ dengan nilai $t$-statistic $1,245<1,96$ dan nilai $\mathrm{p}$ - value $0.214>0,05$, hal ini berarti bahwa tingkat pemahaman akuntansi mempunyai pengaruh yang positif tidak terbukti.

Untuk mengetahui seberapa jauh variabel kecerdasan emosional terhadap prestasi belajar yang di mediasi oleh tingkat pemahaman akuntansi dapat dilihat pada tabel lampiran 18, Hubungan kecerdasan emosional terhadap prestasi belajar yang di mediasi oleh tingkat pemahaman akuntansi mempunyai pengaruh positif yang signifikan $(\mathrm{O}=0,069)$ dengan nilai $t$ statistic $1,306<1,96$ dan nilai $\mathrm{p}-$ value $0.192>0,05$, hal ini berarti bahwa tingkat pemahaman akuntansi mempunyai pengaruh yang positif tidak terbukti.

Pada pengujian hipotesis ini, diketahui bahwa kecerdasan emosional memiliki pengaruh yang negatif terhadap prestasi belajar, hal tersebut disebabkan oleh hasil dari uji statistik yang mana dapat diketahui bahwa nilai $\mathrm{t}$ - statistic pada hubungan ini adalah 1,785 dan nilai $\mathrm{p}$ - value 0.075 . Oleh karena itu, hipotesis tersebut dinyatakan tidak memiliki pengaruh yang positif atau bisa dikatakan memiliki pengaruh yang negatif.

Hasil dari penelitian ini sesuai dengan penelitian-penelitian terdahulu yaitu motivasi belajar mempunyai pengaruh yang positif terhadap prestasi belajar. Sunarti (2018) menyatakan bahwa jika kita belajar tanpa adanya motivasi maka tingkat keberhasilan yang didapatkan akan lebih rendah. Motivasi belajar merupakan penyebab, penyalur, dan juga pendukung dalam perilaku seseorang agar dapat terdorong untuk lebih maksimal dalam mencapai hasil (Yulika 2019).

Hasil dari penelitian ini sesuai dengan penelitian-penelitian terdahulu yaitu kecerdasan emosional mempunyai pengaruh yang positif terhadap tingkat pemahaman akuntansi. Satria \& Fatmawati (2017) mengatakan variabel kecerdasan emosional mempunyai kontribusi pengaruh sebesar $22,5 \%$ yang mana di dalamnya terdapat lima komponen yaitu: pengenalan diri, pengendalian diri, motivasi, empati, keterampilan sosial terhadap pemahaman akuntansi. 
Dalam memahami akuntansi kecerdasan emosional juga memiliki sebuah peran yang penting untuk mencapai kesuksesan (Rokhana \& Sutrisno 2016).

Hasil dari penelitian ini sesuai dengan penelitian-penelitian terdahulu yaitu motivasi belajar mempunyai pengaruh yang positif terhadap tingkat pemahaman akuntansi. Tingkat pemahaman akuntansi sangat dipengaruhi oleh motivasi belajar hal tersebut dikarenakan apabila adanya motivasi yang tinggi maka seseorang akan lebih mudah dalam memahami pembelajaran karena orang tersebut memiliki suatu motivasi untuk menjadi lebih pintar atau lebih cepat dalam menyelesaikan perkuliahannya (Apriandi 2015). Salah satu konsep dalam motivasi belajar yaitu mengoptimalkan kegiatan yang berorientasi pada keberhasilan dalam pencapaian tujuan (Permana 2016).

Pada pengujian hipotesis ini, diketahui bahwa tingkat pemahaman akuntansi memiliki pengaruh yang negatif terhadap prestasi belajar, hal tersebut disebabkan oleh hasil dari uji statistik yang mana dapat diketahui bahwa nilai $\mathrm{t}$ - statistic pada hubungan ini adalah 1,634 dan nilai $\mathrm{p}$ - value 0.103 . Oleh karena itu, hipotesis tersebut dinyatakan tidak memiliki pengaruh yang positif atau bisa dikatakan memiliki pengaruh yang negatif.

Pada pengujian hipotesis ini, diketahui bahwa kecerdasan emosional memiliki pengaruh yang negatif terhadap prestasi belajar, hal tersebut disebabkan oleh hasil dari uji statistik yang mana dapat diketahui bahwa nilai $\mathrm{t}$ - statistic pada hubungan ini adalah 1,245 dan nilai $\mathrm{p}$ - value 0.214. Oleh karena itu, hipotesis tersebut dinyatakan tidak memiliki pengaruh yang positif atau bisa dikatakan memiliki pengaruh yang negatif.

Pada pengujian hipotesis ini, diketahui bahwa kecerdasan emosional memiliki pengaruh yang negatif terhadap prestasi belajar, hal tersebut disebabkan oleh hasil dari uji statistik yang mana dapat diketahui bahwa nilai $\mathrm{t}$ - statistic pada hubungan ini adalah 1,306 dan nilai $\mathrm{p}$ - value 0.192 . Oleh karena itu, hipotesis tersebut dinyatakan tidak memiliki pengaruh yang positif atau bisa dikatakan memiliki pengaruh yang negatif.

\section{Simpulan dan Saran}

Berdasarkan hasil dari analisis dan pembahasan tentang pengaruh kecerdasan emosional dan motivasi belajar terhadap prestasi belajar dengan tingkat pemahaman akuntansi sebagai variabel intervening, maka dapat diberikan beberapa kesimpulan sebagai berikut:

Kecerdasan emosional mempunyai pengaruh negatif terhadap prestasi belajar. Kecerdasan emosional mempunyai pengaruh positif terhadap tingkat pemahaman akuntansi. Motivasi belajar mempunyai pengaruh positif terhadap prestasi belajar. Motivasi belajar mempunyai pengaruh positif terhadap tingkat pemahaman akuntansi. Tingkat pemahaman akuntansi mempunyai pengaruh negatif terhadap prestasi belajar. Motivasi belajar terhadap prestasi belajar dengan tingkat pemahaman akuntansi sebagai variabel intervening mempunyai pengaruh yang negatif. Kecerdasan emosional terhadap prestasi belajar dengan tingkat pemahaman akuntansi sebagai variabel intervening mempunyai pengaruh yang negatif.

Penelitian selanjutnya disarankan untuk melakukan analisis pada hubungan keempat konstruksi dalam penelitian ini dari berbagai jurusan, dengan demikian hasil dari penelitian tersebut dapat di presentasi dan juga dapat di generalisasi pada semua mahasiswa di setiap jurusan yang ada. Selain itu perlu dilakukan pengkajian ulang mengapa kecerdasan emosional mempunyai pengaruh yang negatif terhadap prestasi belajar, tingkat pemahaman akuntansi terhadap prestasi belajar berpengaruh negatif, motivasi belajar terhadap prestasi belajar dengan tingkat pemahaman akuntansi sebagai variabel intervening dan motivasi belajar terhadap prestasi belajar dengan tingkat pemahaman akuntansi sebagai variabel intervening mempunyai pengaruh yang negatif. Apakah itu hanya berlaku untuk mahasiswa akuntansi saja atau ke mahasiswa yang lain juga. 


\section{Daftar Pustaka}

Apriandi, R. F. (2015). Pengaruh Kecerdasan Emosional, Kecerdasan Intelektual, Motivasi terhadap Tingkat Pemahaman Akuntansi dengan Kepercayaan Diri sebagai Variabel Moderating. Jurnal Riset Akuntansi Jambi. https://core.ac.uk/download/pdf/233183672.pdf

Aulia, A., \& Subowo. (2016). Pengaruh Pengendalian Diri, Motivasi, dan Perilaku Belajar terhadap Tingkat Pemahaman Akuntansi Mahasiswa. Economic Education Analysis Journal, 5(1), 346-362.

Chrisna, H., \& Khairani. (2019). Pengaruh Perilaku Belajar, Pengendalian Diri, Motivasi, Empati, Keterampilan, dan Kepercayaan Diri terhadap Prestasi Akademik Mahasiswa PRODI Akuntansi Universitas Pembangunan Panca Budi Medan. Jurnal Akuntansi Bisnis Dan Publik, 10(1), 87-100.

Fitriani, A., \& Otok, B. widjanarko. (2013). Pengembangan Indikator dan Penentuan Rumah Tangga Miskin Dipropinsi Jawa Timur Menggunakan Spatial Structural Equation $\begin{array}{llllll}\text { Modeling. } & \text { Sains } & \text { Dan }\end{array}$ https://doi.org/10.12962/j23373520.v2i1.3187

Fitrio, T., Utami, S., Sobar, M., \& Rizkia, F. (2019). Pengaruh Spritualitas dan Motivasi terhadap Prestasi Belajar Mahasiswa STIE-Indragiri Rengat. Jurnal Ilmiah Mahasiswa Manajemen Dan Bisnis, 02(01), 13-23.

Hutahahean, M. U. B. (2015). Pengaruh Gender, Regigiusitas dan Prestasi Belajar terhadap Perilaku Etis Akuntan Masa Depan (Studi Pada Mahasiswa Akuntansi Perguruan Tinggi Swasta di Wilayah DKI Jakarta). E-Journal Akuntansi Trisakti, 2(1), 49-66. https://doi.org/http://dx.doi.org/10.25105/jat.v2i1.4831

Janti, S. (2014). Analisis Validitas dan Reabilitas dengan Skala Likert terhadap Pengembangan SI/TI dalam Penentuan Pengambilan Keputusan Penerapan Strategic Planning pada Industri Garmen. Snast, November, 211-216.

Lestari, N. P. S. (2013). Pengaruh Motivasi Belajar dan Gaya Belajar terhadap Prestasi Belajar Akuntansi Siswa Kelas X Akuntansi Smk Negeri 1 Sooko Mojokerto. Jurnal Pendidikan Akuntansi (JPAK), 1(1), 1-16.

Mutia, A. (2015). Pengaruh Kecerdasan Emosional dan Perilaku Belajar terhadap Tingkat Pemahaman Akuntansi Mahasiswa ( Studi Empiris Mahasiswa Akuntansi Perguruan Tinggi di Kota Padang ). Jurnal WRA, 3(2), 639-654. https://doi.org/https://doi.org/10.24036/wra.v3i2.6165

Novianto, G., \& Subkhan. (2015). Pengaruh Minat, Motif Berprestasi dan Kesiapan Belajar terhadap Prestasi Belajar Siswa Kelas IX IPS Pada Mata Pelajaran Akuntansi di SMA Negeri 1 Subah Tahun Pelajar 2013/2014. Economic Education Analysis Journal, 4(2), $440-452$.

Novita, D. (2017). Pengaruh Motivasi Belajar dan Kemampuan Numerik terhadap Prestasi $\begin{array}{lllll}\text { Belajar Akuntansi. } & \text { Jurnal }\end{array}$ https://doi.org/http://dx.doi.org/10.30998/sap.v2i1.1251

Nugrahadi, W., \& Rizki, A. (2018). Pengaruh Kecerdasan Emosional dan Motivasi Belajar terhadap Prestasi Belajar Ekonomi Siswa Kelas X IIS SMA Negeri 1 Raya Tahun Pelajaran 2017/2018. Jurnal Ekonomi Pendidikan, 8(September), 1-18. 
Palgunadi, A. P., \& Rohayati, S. (2014). Pengaruh Hasil Belajar Matematika, Ekonomi dan Minat Belajar terhadap Tingkat Pemahaman Akuntansi. Jurnal Pendidikan Akuntansi Universitas Negeri Surabaya, 1-7.

Parauba, I. (2014). Pengaruh Kecerdasan Intelektual, Kecerdasan Emosional, Kecerdasan Spiritual, dan Perilaku Belajar terhadap Pemahaman Akuntansi Mahasiswa Fakultas Ekonomi dan Bisnis Universitas Sam ratulangi Manado. 9(2), 53-67. https://doi.org/https://doi.org/10.32400/gc.9.2.5059.2014

Permana, A. (2016). Pengaruh Gaya Belajar dan Motivasi Belajar Mahasiswa terhadap Kemampuan Belajar Ilmu Alamiah Dasar. Jurnal Formatif, 6(3), 276-283. https://core.ac.uk/download/pdf/233183672.pdf

Undang-Undang Republik Indonesia Nomor 12 Tahun 2012 tentang Pendidikan Tinggi, www.hukumonline.com 1 (2012). https://unasman.ac.id/download/UU-12-THN-2012TENTANG-PENDIDIKAN-TINGGI(1).pdf

Rimbano, D., \& Putri, E. S. M. (2016). Pengaruh Kecerdasan Emosional, Kecerdasan Spiritual, dan Perilaku Belajar pada Tingkat Pemahaman Akuntansi. Jurnal Ilmiah Orasi Bisnis, 15(1), 988.

Rokhana, L. A., \& Sutrisno, S. (2016). Pengaruh Kecerdasan Emosional, Perilaku Belajar dan Minat Belajar terhadap Tingkat Pemahaman Akuntansi. (Studi Empiris Pada Mahasiswa Akuntansi Fakultas Ekonomika dan Bisnis UNTAG Semarang) Linda. Media Ekonomi Dan Manajemen, 31(1), 26-38. https://doi.org/http://dx.doi.org/10.24856/mem.v31i1.282

Sari, R. N., Santoso, S., \& Hamidi, N. (2015). Pengaruh Kecerdasan Emosional dan Lingkungan Belajar Terhadap Hasil Belajar Akuntansi Siswa. Tata Arta UNS, 1(2), 294-312. http://jurnal.fkip.uns.ac.id/index.php/tataarta/article/view/6741/4606

Satria, M. R., \& Fatmawati, A. P. (2017). Pengaruh Kecerdasan Emosional terhadap Tingkat Pemahaman Akuntansi Pada Mahasiswa Akuntansi Di Kota Bandung. Amwaluna: Jurnal Ekonomi Dan Keuangan Syariah, 1(1), 66-80. https://doi.org/10.29313/amwaluna.v1i1.2022

Setyorini, D., \& Syahlani, A. (2019). Analisis Jalur (Path Analysis) Pengaruh Kondisi Sosial Ekonomi dan Motivasi Belajar terhadap Prestasi Belajar Mahasiswa. Jurnal Akuntansi Dan Manajemen, 16(02),
https://doi.org/https://doi.org/10.36406/jam.v16i02.241

177-193.

Sunarti, I. (2018). Pengaruh Kecerdasan Emosi, Efikasi diri dan Motivasi Belajar terhadap Prestasi Belajar Mahasiswa Pendidikan Ekonomi UNIKU. Equilibrium: Jurnal Penelitian Pendidikan Dan Ekonomi, 15(2), 16-33. https://doi.org/10.25134/equi.v15i02.Abstract

Suprianto, E., \& Harryoga, S. (2016). Faktor-Faktor Penentu Tingkat Pemahaman Akuntansi. Jurnal Ekonomi Dan Bisnis, 18(3), 75. https://doi.org/10.24914/jeb.v18i3.281

Wibowo, N. C., \& Sutanto, E. M. (2013). Pengaruh Kualitas Leader Member Exchange (LMX) terhadap Produktivitas Kerja Melalui Kepuasan Kerja dan Komitmen Organisasional Pada PT Nutrifood Surabaya. Jurnal Manajemen Dan Kewirausahaan (Agora), 1(1), 1-10.

Wiyono, M. W. (2012). Pengaruh Kecerdasan Emosional terhadap Tingkat Pemahaman Akuntansi. Journal of the Royal Society of Medicine, 2(2), 1364-1365. 
https://doi.org/10.1177/003591573402701034

Yulika, R. (UIN A. M. (2019). 252 Pengaruh Kecerdasan Emosi.... Journal Uin Aluddin Makassar, 252-270. https://doi.org/https://doi.org/10.24252/ip.v8i2.7838 